\title{
Innovative Gastronomic Tourism as a New Trend. Evidence from Kazakhstan
}

\author{
Dr. Almaz Sandybayev" (ADMC) \\ Assistant Prof., Higher Colleges of Technology, Abu Dhabi Men's College, Faculty of Business, United Arab \\ Emirates
}

*Corresponding Author: Dr. Almaz Sandybayev, Assistant Prof., Higher Colleges of Technology, Abu Dhabi Men's College, Faculty of Business, United Arab Emirates

\begin{abstract}
Under the conditions of a dynamically developing tourism which occupies one of the central places in the world economy, there is an urgent need to strengthen its position in Kazakhstan where the country's tourism potential is used at a very low level. The article highlights the main aspects of gastronomic tourism as a recent trend of tourism. The purpose of this article is to discover the main concepts of innovative gastronomic tourism as an opportunity for the development of territories and their active participation in the formation of innovative tourism attractiveness. Selected world top gastronomic tours and excursions experience are discussed according to the largest travel site Trip Advisor. An attempt to analyze gastronomic tourism as a promising type of development of regions in Kazakhstan has been taken by utilizing qualitative expert interviews.
\end{abstract}

Keywords: Gastronomic Tourism, Innovation, Kazakhstan.

\section{INTRODUCTION}

Visiting other countries in order to familiarize or enjoy the cuisine or culinary culture is a great idea for those who want to get new impressions. Gastronomic tourism is called tasteful travel, because culinary pleasures sometimes best help to understand the culture of a particular people or nation. According to Cohen and Avieli (2004), through food, tourists receive a greater engagement with the environment where the visit takes place, far from the role of simple observer traditionally associated with tourist visits. The travelers can be interested in the local food and in obtaining gastronomic experiences and these experiences can even play an important role in the choice of the destination and in their level of satisfaction (Basil, 2009).

It is food that is an important means of penetrating into another culture and making it possible to feel "other" not only on an intellectual but also on a sensory level. Local food is the main attribute of the destination, adding sensations to the overall tourist experience. This makes food an integral part of tourism production and consumption, increasing its role in the successful development of the entire tourism industry. As argued by Hall et al. (2003), food tourism is defined as a kind of tourism aimed to visit food producers, attend food festivals and eat at restaurants. Lee (2015) proposed one of the most used definitions of gastronomic tourism, where gastronomic tourism "is a journey, in regions rich in gastronomic resources, to generate recreational experiences or have entertainment purposes which include: visits to primary or secondary producers of gastronomic products, gastronomical festivals, fairs, events, cooking demonstrations, food tastings or any activity related to food". Nutrition is one of the elements included in the new concept of cultural heritage and cultural tourism which is due to the growing tendency to desire well-being in life, authenticity of feelings, environmental protection and the desire to get exactly quality experience while traveling.

The term culinary tourism was introduced into circulation in 1998. The tourism industry, like other areas of human activity is actively undergoing changes and innovations, namely, the nature and structure of this industry is changing. According to a survey from World Tourism Organization, over $88 \%$ of its members believe that gastronomy is a strategic element in defining the destination brand and image, and over $67 \%$ say that their country has its own gourmet brand. In terms of tourism products, the study conducted has shown that the most important are: gastronomic events (79\%), 
gastronomic routes $(62 \%)$, cooking courses and workshops $(62 \%)$, visits to local markets and producers $(53 \%)$ (WTO, 2012).Based on demand, new ways and types of integrated tourism are appearing to change the standard form. This process governs by innovation. Innovation is a new product, a new phenomenon or action in the market which aims to attract the consumer, satisfy customer's needs and at the same time generate income to the entrepreneur.

Tourism development remains a relatively new sector in Kazakhstan. Kazakhstan has great potential in this area. The country is rich in diverse natural, cultural and geographical sights. Despite the huge tourism potential of Kazakhstan, tourism in the country has never developed properly. The share of tourism in the national gross product (GDP) is only $0.3 \%$. Today, tourism is one of the most priority and promising sectors for Kazakhstan as a whole and the regions. Almost in all countries of Europe and the world the tourism sector receives massive support and advancement from regional and local governments. Regulatory issues regulation and international marketing are often the only areas of direct interest from national / central level authorities. The remaining issues are resolved rather at regional than national level. State support of tourism is a prerequisite for the sustainable development of the industry. International experience proves that active policies for the development of tourism infrastructure, attracting private investors, developing a regulatory framework and ensuring favorable economic conditions for work will allow the tourism industry to play an important role in the socioeconomic development of the country. In addition, it is the role of Governmentto actively develop tourism, allocate significant budget funds for the implementation of national projects and programs and provide high-quality travel services to its citizens and visitors. Thus, the article tries to discover the state and prospects of development of gastronomic tourism, first, considering the world experience, second, the experience of Kazakhstan by specifying the role of innovation gastronomy as a new trend in this development.

\section{LITERATURE REVIEW}

\subsection{Tourism as a Social Economic Benefit}

Tourism plays an important role in solving social problems, providing job creation, employment growth and welfare of the population and country. Currently tourism is one of the important areas affecting economic growth, including on the development of such areas of economic activity as tourist services companies, accommodation facilities, transport, communications, trade, production, food, agriculture, construction and other industries, thus acting as a catalyst of socio-economic development. It has an important role in terms of employment through succeeding in lower the unemployment, thereby drawing the surplus labor from other sectors (Nica, 2011).

According to forecasts of experts of the World Tourism Organization (2016), the global tourism industry is entering a period of constantly increasing volume of travel and excursions, increasing competition among regions and countries of stay. At the same time, a large number of well-informed consumers of tourism services appear, paying attention to the quality and safety of the offered product. Further development of the global tourism market is increasingly determined by the latest information technologies.

\subsection{Innovation Gastronomic Tourism}

Innovation in the field of tourism is aimed at creating a new or changing an existing product, at improving transport, hotel and other services, introducing advanced information and telecommunication technologies and improved forms of organizational and management activities. Innovative activity in the field of tourism services is developing in several areas:

- Release of new types of tourism products;

- Use of new tourism resources;

- Change in the organization of production and consumption;

- Identification and use of new markets for products;

- Use of new technologies

The organization of gastronomic tourism in the world top tourism countries takes place both at the state and regional levels. Tourist companies are actively developing and promoting gastronomic tours, itineraries, and excursions. Various culinary festivals, contests, shows take place. Notion of culinary 
tourism was put forward and defined by Long (2004)as a global activity in which people participate in "other" food culture, including tasting, consumption, preparation and display food.

Gastronomic tourism is supported not only by developing attractive form from a culinary point of view and tourist products but also by authoritative organizations involved in the development of this area in tourism. Examples include the following organizations:

- International Culinary Tourism Association (ICTA);

- World Food Travel Association (WFTA);

- Spanish Association of Culinary and Tourism (Spanish Association of Wine and culinary tourism).

The national cuisine is worthy of the attention of tourists traveling for gastronomic purposes. Top gastronomic tour routes and excursions of the world according to the largest travel site Trip Advisor are presented in the Table 1.

Table1. Top gastronomic tour routes

\begin{tabular}{|c|c|c|}
\hline Place of the tour & Name of the tour & Description of the tour \\
\hline Lisbon (Portugal) & «YourFriendinLisbon» & $\begin{array}{l}\text { Four-hour private tour with a Lisbon tasting and tapas } \\
\text { expert. Tourists can taste homemade Portuguese } \\
\text { cheese, delicious chorizo, delicious Iberian pork } \\
\text { sausages, unique ham } \\
\text { Patanegra, premium virgin olive oil, homemade } \\
\text { preserves and traditional bread. In addition to this, } \\
\text { there is a tasting of five types of port wine, including } \\
\text { the famous "Vintage". }\end{array}$ \\
\hline Las Vegas (USA) & $\begin{array}{l}\text { «LipSmackingFoodieTo } \\
\text { urs» }\end{array}$ & $\begin{array}{l}\text { Walking tour with a competent Las Vegas Strip ( } 2.5 \\
\text { hours). Tourists will be able to visit the four famous } \\
\text { Las Vegas restaurants and sample up to } 12 \text { wonderful } \\
\text { dishes prepared by the best chefs. }\end{array}$ \\
\hline $\begin{array}{l}\text { London } \\
\text { (United Kingdom) }\end{array}$ & «EatingLondonFoodTours» & $\begin{array}{l}\text { A tour of the East - End in London in the Spitalfields } \\
\text { and Shoreditch district with a friendly guide will allow } \\
\text { tourists to find out where the locals eat in London. }\end{array}$ \\
\hline $\begin{array}{l}\text { Puerto - Vallarta } \\
\text { (Mexico) }\end{array}$ & «VallartaFoodTours» & $\begin{array}{l}\text { Puerto-Vallarta walking tour ( } 3.5 \text { hours) allows to } \\
\text { look at the culture of the country through the eyes of a } \\
\text { local through delightful and multi-faceted Mexican } \\
\text { cuisine. Tourists stop in ten different places and try } \\
\text { everything that relates to local cuisine: the best } \\
\text { enchiladas in Vallarta, traditional ceviche for toasts, } \\
\text { fresh coconuts, original tacos, national drinks, spicy } \\
\text { soups, local sweets and much more. }\end{array}$ \\
\hline Tokyo (Japan) & «Tokyo FooDrink Tour» & Tsukiji Fish Market Tour with Sushi Master Class. \\
\hline $\begin{array}{l}\text { Melbourne } \\
\text { (Australia) }\end{array}$ & «Vinetrekker -DayTours» & $\begin{array}{l}\text { Day gastronomic and wine tour } \\
\text { Yarra Valley from Melbourne, including lunch at } \\
\text { restaurant "YeringStation". }\end{array}$ \\
\hline $\begin{array}{l}\text { San Sebastian } \\
\text { (Spain, Donostia) }\end{array}$ & «SanSebastianFood» & $\begin{array}{l}\text { San Sebastian wine tour for small } \\
\text { pincho tasting groups. }\end{array}$ \\
\hline
\end{tabular}

\subsection{Gastronomic Tourism in Kazakhstan}

Kazakhstan is a multinational country occupying a huge territory of the globe, it keeps a lot of historical and cultural monuments of the people living there. Gastronomic tourism is a new and promising type of tourism, the main purpose of which is to get acquainted with a particular country through the prism of national cookery. Gastronomic tourism is one of the fastest growing in the CIS countries. Kazakhstan has the potential to develop gastronomic tourism. The history of culinary (gastronomy) of Kazakhstan is inextricably linked with the history of the development and formation of Kazakhstani society as a whole.

Initially, the history of the emergence of domestic culinary takes its origins in the culture and life of nomadic civilizations, in this regard, the basis of the Kazakh national cuisine is the skillful preparation of meat dishes from meat of various animal species that are capable of long movements. In this regard, the Kazakh national cuisine has acquired a special art and specificity in the preparation of 
delicious dishes from a seemingly limited range of products caused by the life of nomads. As a result, national Kazakh cookery brands emerged: Kazakh-style meat, delicacies of horse meat -'kazi and zhaya', boiled lamb carcasses and cheese, boiled in their own juice, cheese, dairy products - unique 'nan', 'bauyrsak' and much more. The historical commonality with the ancient civilizations of the neighbors brought the flavor of eastern sedentary cultures in the form of pilaf, mantas, lagman and other numerous Central Asian dishes. The formation of the Great Silk Road and the cuisines of the peoples who inhabited it including the Uigur and Dungan peoples, had a definite influence on the formation of the national cuisine.

19-20 century had a huge influence on the multinational character of the formation of Kazakhstani cuisine. The history of relations with the Russian Federation, the peoples who lived in the former Soviet space. Multinational Kazakhstan has become home to representatives of more than 130 ethnic groups, each of which has its own special, national cuisine. As a result, the local cuisine was enriched with a huge variety of cuisines of all nationalities of the former Soviet Union. Russian 'borsch', 'dumplings', 'shashlik' and many other things have become part of the daily diet of people in Kazakhstan. Table 2 represent some of Kazakh national dishes.

Table2. Kazakh national dishes

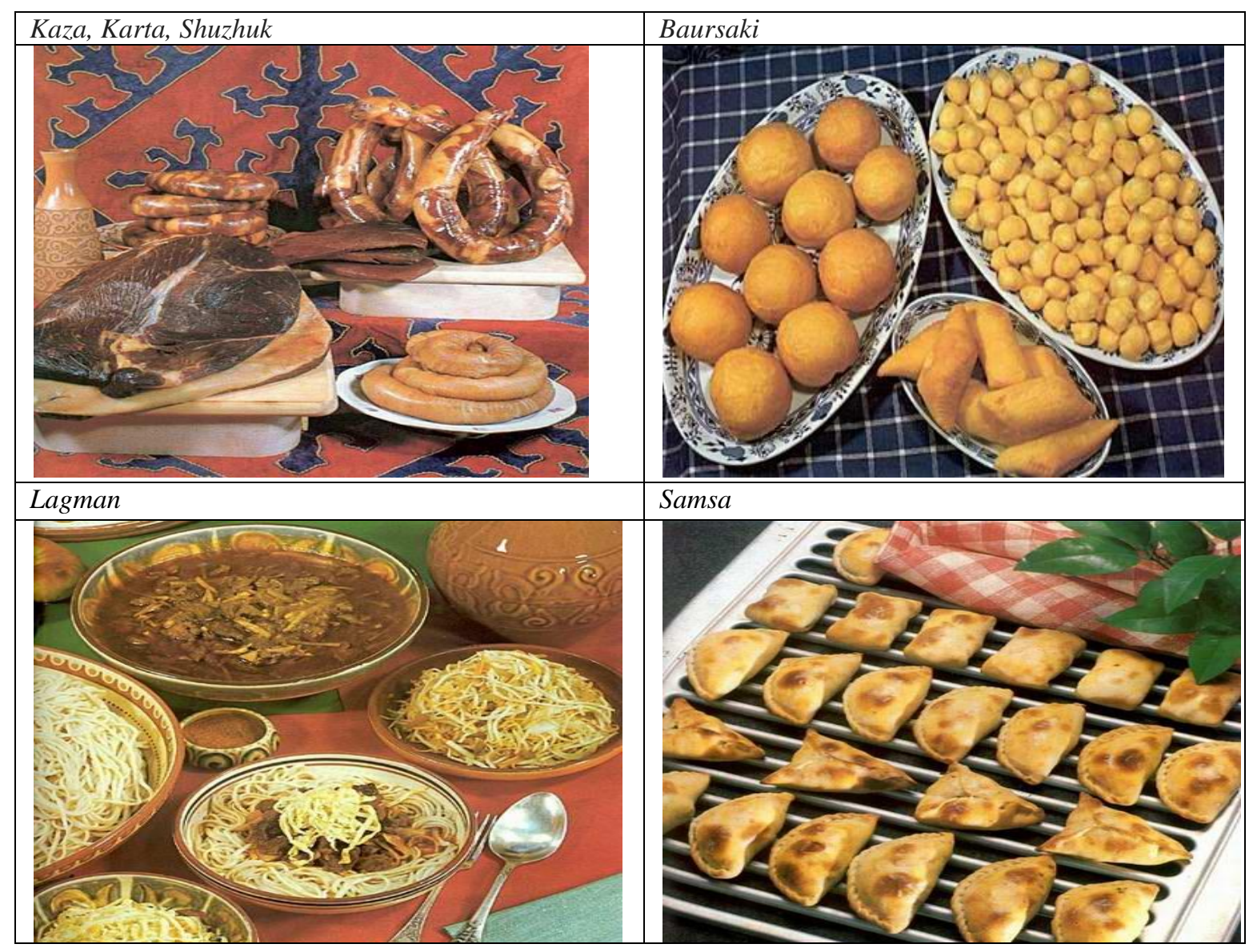

As a result of the recent decades of globalization of the world economy, the Kazakhstani restaurants have adopted the best trends of world cuisine: Italian cuisine, European cuisine, fast food and panAsian cuisine. Thus, Kazakhstan is a unique gastronomic project, a feature of which is the interweaving of the historical and cultural culinary past with the preservation of a pronounced national presence. Another culinary feature of Kazakhstan is that dishes are prepared from environmentally friendly products without the use of genetically modified organisms (hereinafter GMOs) and preservatives. Dishes of different nations, prepared from environmentally friendly products without GMOs and preservatives may potentially increase the interest in inbound tourism. For the development of gastronomic tourism the following initiatives have been developed in Kazakhstan:

- The work has been strengthened with the entrepreneurs in the sphere of restaurant business, as well as related fields of activity in order to determine the levers contributing to the efficient 
operation of instruments of state support at the local level. Gastronomic tourism development measures will include economic incentives for SMEs.

- Thematic gastronomic tours in tourist clusters have been developed;

- It is agreed to hold gastronomic festivals - food shows, master classes, during which tourists will have the opportunity to take part in cooking.

But, despite the measure taken, gastronomic tourism in Kazakhstan is still a rare concept. Lack of thoughtful routes and poor infrastructure don't make good publicity for this kind of travel and few travelers be ready to pay to cross the endless expanses with the aim to try this or that dish.

The factors inhibiting the development of gastronomic tourism in Kazakhstan include:

- Lack of experience of local tour operators in the organization of gastronomic tours;

- High cost of gastronomic tours;

- Insufficient quality of customer service at tourism enterprises and hospitality.

In Kazakhstan, the elements of gastronomic tour operators are rarely included in the main programs and the gastronomic concept of the trip itself is a rarity. There is no clear system of gastronomic tours. Specific features of gastronomic tourism in Kazakhstan include:

- Conditions for the development of gastronomic tourism in all regions of Kazakhstan;

- Gastronomic tourism is not a seasonal holiday;

- Culinary tourism is to some extent a constituent element of all tours but unlike other types of tourism familiarity with the national cuisine becomes the main motive, purpose and element of gastronomic travel;

- Promotion of local farms and food producers - is an integral part of any gastronomic tour.

The factors favoring the development of gastronomic tourism (in addition to resources) include: the ability to create new jobs and involve local residents in the workflow; availability of diverse natural and recreational potential, rich cultural and historical heritage; the presence of higher educational, vocational education and training centers in tourism and hospitality; organization of large international and regional business, cultural, recreational and sporting events. Gastronomic tourism has proven to be a fairly profitable item of the state economy and it is not by chance that even those countries of gastronomic culture took up its development. However, despite the existing situation in Kazakhstan, more and more businesses understand the prospects and future of this trend.

\section{RESEARCH DESIGN}

The research design addressed the examination of experts in Kazakhstan through short interview questions. Thus, qualitative methods utilization has been used for this research. As Rossman and Rallis (1998) noted, "there are few truths that constitute universal knowledge; rather, there are multiple perspectives about the world". The study was organized in a way to understand different variations in the interpretation of gastronomic tourism development in Kazakhstan. Merriam (1998) argued that qualitative research offers "the greatest promise of making significant contributions to the knowledge base and practice of education" because it is "focused on discovery, insight, and understanding from the perspective of those being studied".

\subsection{Qualitative Interview}

Expert telephone interview has been selected to manage out this research study. Expert type of questions allows the participants to elaborate and with that provided more flexibility to elicit more information from the participant. Kumar (2005) views the interview as the most suitable approach for studying complex and sensitive areas as the interviewer has the opportunity to prepare a participant before asking sensitive questions and to explain complex ones to them in person.

The telephone interview has some freedom to probe and explore additional questions in response while at the same time creating rapport and empathy. Each expert was given same open ended question to evaluate the stage of development of gastronomic tourism. An example of an open ended question included in the interview was 'What is your expectation and understanding of gastro tourism 
in Kazakhstan?' Open ended questions like this allow the participant more scope to express thoughts and feelings (especially when sensitive issues are being discussed) and can offer more detail on the research subject (Sarantakos, 1988).

\section{Results}

As discussed, gastronomic tourism in Kazakhstan has not yet taken shape as an independent direction, however, representatives of the tourism industry and restaurant business predict good prospects for it, provided that the infrastructure and convenient routes for travelers are created. Here below is a short reflection of telephone interview results:

\section{Expert 1:}

"This is one of the most promising areas of tourism development in Kazakhstan. Gastronomic tourism is one of the most powerful drivers for the development of the tourism industry and a promising direction for realizing the country's export potential".

Expert 2:

"The World Tourism Organization, based on the results of a study in 2017, concluded that gastronomic preferences are one of the main factors for a tourist to make a decision to travel to a particular country".

According to the expert, nowadays, most people try to appreciate the culture of the country they come to and gastronomy is a very important part of the perception of the cultural code of the state that receives tourists.

\section{Expert 3:}

"I am confident that the creation of a proper and organized gastronomic tourism is hampered by the lack of interaction between restaurants and travel companies. Some expect that tourists will be brought to them".

Interestingly that all experts agree on potential degree of gastronomic tourism in Kazakhstan and see it as a base for the future economic development. All participants reported the growing role of gastronomic tourism but highlighted that current impact is not significant as in other countries.

For the development of the gastronomic potential of Kazakhstan, it is possible to use the European and international experience in the formation of a gastronomic basket of the best products region. Actually, this network still does not exist in Kazakhstan, it exists in France as example, where in recent years life in the countryside has been considered more and more prestigious. And French gastronomy is recognized as part of UNESCO World Heritage.

The following possible paths for the development of gastronomic tourism in the world, which can be successfully applied for Kazakhstan:

- Development of culinary tourist resources which characterize the region.

- Development of destinations with the possibility of receiving numerous tourist impressions including gastronomic.

- Cooperation between private tourist and gastronomic producers' services.

- Application of an effective marketing strategy of destinations which includes gastronomic offers, raising public awareness about this form of tourism.

- Increase the self-awareness of the population through the promotion of local food culture.

With the increasing competition in tourism and its marketing, each region is looking for unique products with which to differentiate. By itself, local cuisine is already the platform that contains the necessary resources that can be used as a marketing tools for attracting customers, promoting cities, regions or even whole countries.

\section{CONCLUSION}

Gastronomic tourism is one of the specific, relatively young and developing areas of tourism. Specificity is manifested in the possibility of the universal development of this sphere, in the variety 
of manifestations of gastronomic tours in any season of the year, in the ability to promote local farms and producers of food products. Kazakhstan gastronomic tourism obviouslyhas some disadvantages to this direction today: there are no well-thought-out tours, and those tours that exist have a high cost.An analysis of the world's gastronomic centers showed that European countries are leading in the market of gastronomic tourism, namely Italy, France, Spain. In other regions of the world, gastronomic tours are equally in demand. Among them are the USA, Argentina, Japan, and Australia. Various international programs are being developed for the development of gastronomic tours. The issue of food is inextricably linked with the history of mankind. The food itself, being tightly connected with history, becomes a product of historical and cultural significance. Food is considered as a peculiar language (cultural code) and at the same time as one of the methods of self-identification of a people. Like the cuisines of other nations of the world, Kazakhstani's cuisine is specific. Its specificity is manifested in the multicultural nature of society, and as a result, the diversity of culinary traditions. In this regard, it gets the opportunity to develop a new type of tourism - gastronomic tourism. Today, these are tours where there are no firmly established routes; only some large tour operators which are confident in their abilities and partners are engaged in their organization. The representatives of the tourism business state that this direction has formed a narrow but permanent circle of supporters. This statement allows to talk about the prospects for the development of culinary travels: think over routes, create advertising to attract more tourists. And then such tours will be in demand both individually and in large numbers.

Summing up, it can be stated that gastronomic tourism in the future may become a popular travel, because today people prefer refined and memorable holidays and a deep knowledge of the region visited through understanding and tasting national cuisine.

\section{REFERENCES}

[1] Basil M. and Basi D.Z. (2009). Reflections of ultra-fine dining experiences. In: Lindgreen A, Vanhamme J and Berveland MB, editors. Memorable customer experiences: a research anthology. Surrey: Gower Publishing Company, 135-138.

[2] Cohen, E.; Avieli, N. Food in tourism: Attraction and Impediment. Ann. Tour. Res. 2004, 31, 755-778.

[3] Hall, C. M. (2003). Food tourism around the world: development, management and markets. Oxford: ButterworthHeinemann.

[4] Kumar, R. (2005). Research Methodology - A Step by Step Guide for Beginners. (2nd Ed.). London: SAGE Publications Ltd.

[5] Lee, K.H., Packer, J. and Scott, N. (2015). Travel lifestyle preferences and destination activity choices of slow food members and non-members. Tourism Management, 46, 1-10.

[6] Long, L.M. (2004). Culinary tourism: A folkloristic on eating and otherness. In culinary tourism; Long, L.M., Ed.; The University Press of Kentucky: Lexington, KY, USA, 20-50.

[7] Merriam, S. B. (1998). Qualitative research and case study applications in education. San Francisco: Jossey-Bass.

[8] Nica, A. (2011). Overview of the Romanian and Spanish approaches on the tourism economic impact, Measurement methods. Cactus Tourism Journal, 2(1), 16-25.

[9] Rossman, G. B., and Rallis, S. F. (1998). Learning in the field: An introduction to qualitative research. Thousand Oaks, CA: Sage.

[10] Sarantakos, S. (1998). Social Research. Hampshire: Palgrave.

[11] WTO (2012). Global report on food tourism. Madrid: World Tourism Organization.

Citation: Dr. Almaz Sandybayev. "Innovative Gastronomic Tourism as a New Trend. Evidence from Kazakhstan". International Journal of Research in Tourism and Hospitality (IJRTH), vol 5, no. 1, 2019, pp. 17. doi: http://dx.doi.org/10.20431/2455-0043.0501001.

Copyright: (C) 2019 Authors. This is an open-access article distributed under the terms of the Creative Commons Attribution License, which permits unrestricted use, distribution, and reproduction in any medium, provided the original author and source are credited. 